\title{
Biological Control of Onion White Rot Disease Caused by Sclerotium cepivorum
}

\author{
Warda A. Hussain ${ }^{1,2}$, A. A. Elzaawely ${ }^{1 *}$, N. I. El Sheery ${ }^{1}$, A.A. Ismail ${ }^{3}$ and H.M. El- \\ Zahaby $^{1}$ \\ $1^{1 *}$ Department of Agricultural Botany, Faculty of Agriculture, Tanta University, Tanta, \\ ${ }^{2}$ Department of Integrated Control, Agricultural Research Station, Gemiza, \\ ${ }^{3}$ Department of Integrated Control, Agricultural Research Institute, Giza, Egypt.
}

\begin{abstract}
NION (Allium cepa L.) is a very important vegetable crop in Egypt and all over the world. White rot is a serious disease of Allium spp. caused by the soil-borne fungus Sclerotium cepivorum. In this study, three Trichoderma species and one vegan compost, alone or in combinations with the fungicide folicur were tested for their ability to inhibit mycelial growth of S. cepivorum. The results of the laboratory experiment showed that T. hamatum is the most effective as it recorded the highest inhibition (100\% over growth) of the mycelial growth of the fungus followed by $T$. viride (64.6\%) and T. harzianum $(63.5 \%)$. The results indicated also that the compost tea caused inhibition of the fungus by $57.1 \%$. In the pots experiment, folicur showed the highest efficiency $(75.0 \%)$ to reduce the disease incidence, followed by $T$. harzianum combined with $T$. hamatum and folicur combined with $T$. viride and $T$. hamatumthat had $70.8 \%$ efficiency.
\end{abstract}

Keywords: Sclerotium cepivorum, White rot, Onion, Biological control, trichoderma.

\section{Introduction}

Onion (Allium cepa L.) has important position among all vegetable crops in Egypt. The dryland area cultivated with onion in Egypt reached 68,487 ha and producing 2,505,189 tons annually (FAO, 2014). Onion plants are subjected to various phytopathogens that cause considerable loss in quantity and quality of onion yield. Whiterot disease caused by Sclerotium cepivorum is one of the most essential diseases around the world that causes yield loss up to $100 \%$ (Yesuf, 2013).

The fungus produces long-lived survival structures named sclerotia (Ahmed and Ahmed, 2015) that can stay in the soil without having a host plant for over 20 years. They start to develop and germinate within the sight of Allium plants particularly root exudates. By this way, the sclerotia cause the infection exceptionally particular to Allium species as they penetrate onion plants causing white rot disease (Maude, 2006; Davis et al., 2007). Control of this disease has been accomplished primarily by chemical fungicides such as folicur (Pung et al., 2008). Due to concerns of health and environmental hazards and many pathogens could develop resistance against most recommended fungicides, there is a great demand for safer, alternative and effective control agents. The objective of this study was to control the onion white rot disease caused by $S$. cepivorum by using some fungal isolates as bioagents.

\section{Materials and Methods}

Isolation and identification of the pathogen

Onion plants showing white rot symptoms were collected from different localities of ELGharbia, El-Dakahlia and Giza Governorates. Diseased bulbs were washed with tap water, cut into small pieces and surface sterilized by $0.5 \%$ sodium hypochloride solution for two minutes and then, washed three times with sterilized distilled water. Samples were dried between two layers of sterilized filter papers to remove the excess water and placed on potato dextrose agar (PDA) medium in Petri dishes. Inoculated dishes were incubated at $18-20{ }^{\circ} \mathrm{C}$ for $4-5$ days, and the developed fungal cultures were purified by using hyphal tip isolation techniques (Brown, 1924). Identification of the fungal isolates was carried out according to Ciements and Shear (1957). The obtained pure cultures were kept at $5{ }^{\circ} \mathrm{C}$ on PDA slants for further studies.

*Corresponding author: Abdelnaser A. Elzaawely (elzaawely@agr.tanta.edu.eg)

DOI : $10.21608 /$ jenvbs.2017.1547.1008

C2017 National Information and Documentaion Center (NIDOC) 


\section{Pathogenicity test}

Five isolated of $S$. cepivorum were tested for their pathogenicity against onion cultivar (Giza 20) under greenhouse conditions during $2013 / 2014$ season. Plastic pots ( $25 \mathrm{~cm}$ in diameter) were filled with sterilized soil. The experiment was carried out in a randomized complete block design with three replicates for each particular treatment. According to the methods of Abd ElMoity (1976), inoculate of S. cepivorum isolates were separately prepared. Glass bottles of 500 $\mathrm{ml}$ capacity containing $100 \mathrm{~g}$ barley grains and $50 \mathrm{ml}$ water were autoclaved and then, they were inculcated with $5 \mathrm{~mm}$ diameter discs of pathogenic fungal isolates using 10 days-old cultures and incubated at $18-20^{\circ} \mathrm{C}$ for 25 days. At the greenhouse of Gemiza Research station, four healthy onion seedlings (60 days old) were transplanted in each pot containing $3 \mathrm{~kg}$ soil. The soil was infested with the tested fungus at a rate of $2 \%$ fungus to soil $(\mathrm{w} / \mathrm{w})$. The soil was then moistened with water for two weeks before transplanting.

\section{Laboratory experiment}

Three fungal antagonists'viz., Trichoderma viride, T. harzianum and T. hamatum were evaluated in vitro against the most aggressive isolate of $S$. cepivorum applying dual culture technique (Cherif and Benhamou, 1990). Each treatment replicated 3 times and incubated at $27 \pm 1^{\circ} \mathrm{C}$ until the growth of control treatment (with only plant pathogen disk) covered the Petri dish. The effect of Trichoderma strains on plant pathogens was determined by the percentage of mycelia growth inhibition calculated with the following formula according to Castillo et al. (2011) .

Inhibition $(\%)=[(\mathrm{D} 1-\mathrm{D} 2) / \mathrm{D} 1] \times 100$, where D1 is the growth of the phytopathogen in the absence of antagonist, while D2 is the growth of the phytopathogen in the presence of antagonist. The days of contact between plant pathogen-antagonistic and antagonistic ability of Trichoderma isolates according to the methodology proposed by Bell et al. (1982) were also determined using the following scale:

Class $1=$ The antagonist completely overgrown the pathogen $(100 \% \quad$ overgrowth $) \backslash$

Class $2=$ The antagonist overgrown at least $3 / 4$ th of pathogen surface ( $75 \%$ overgrowth).

Class 3 = The antagonist colonized on half of the growth of the pathogen (50\% overgrowth).

Class $4=$ The pathogen and the antagonist locked at the point of contact.

Class $5=$ The pathogen overgrown the mycoparasite.

To study the effect of vegan compost on $S$. cepivorum isolate, one $\mathrm{kg}$ of a vegan compost provided from Gemmeiza research station was immersed in $10 \mathrm{~L}$ water and filtered to obtain tea compost. Some chemical properties of compost were described in Table 1. Four concentrations of compost tea $(25,50,75$ and $100 \mathrm{mg} / \mathrm{ml})$ were evaluated in vitro against the aggressive isolate of $S$. cepivorum. The requisite quantity of each concentration was calculated and mixed thoroughly with autoclaved and cooled $\left(45^{\circ} \mathrm{C}\right)$ PDA medium, while sterilized distilled water was used as a negative control. Compost amended PDA medium was then poured aseptically in Petri plates $(7 \mathrm{~cm})$ and allowed to solidify. After solidification of medium, all the plates were inculcated aseptically with $5 \mathrm{~mm}$ culture disk of 7-day old culture of $S$. cepivorum and incubated at $18-20^{\circ} \mathrm{C}$ until mycelial growth of pathogenic fungi covered the surface of medium in control treatment (after 7 days). The percent of growth inhibition of the test pathogen was calculated using the formula according to Otadoh et al. (2011) as follows:

$\mathrm{I}=(\mathrm{C}-\mathrm{T} / \mathrm{C}) \times 100$, where $\mathrm{I}=$ Percent inhibition (Reduction), $\mathrm{C}=$ Growth diameter of the pathogen in control and $\mathrm{T}=$ Growth diameter of the pathogen in treatment.

TABLE 1. Some chemical and physical properties of the vegan compost.

\begin{tabular}{lc}
\hline Property & Value \\
\hline Acidity $(\mathrm{pH})$ & $5.85(1: 5)$ \\
EC $\left(\mathrm{dS} \mathrm{m}^{-1}\right)$ & $8.35(1: 5)$ \\
Organic carbon (\%) & 11.85 \\
Total nitrogen (\%) & 1.18 \\
Potassium (\%) & 1.8 \\
Phosphorus (\%) & 0.44 \\
C/N ratio & $1: 10.04$ \\
Calcium (\%) & 0.91 \\
Manganese (ppm) & 388.0 \\
Zinc (ppm) & 12.55 \\
Copper (ppm) & 7.18 \\
Ferric (\%) & 1.05 \\
\hline
\end{tabular}

To study the effect of fungicide (folicur) against mycelial growth of $\mathrm{S}$. cepivorum, six concentrations $(0.02,0.05,0.2,0.4,0.8$ and $1 \mathrm{ppm})$ of folicur were evaluated against $S$. cepivorum. Based on active ingredient, the requisite quantity of each 
fungicide was calculated and mixed thoroughly with autoclaved and cooled $\left(45^{\circ} \mathrm{C}\right)$ PDA medium, while sterilized distilled water was used as negative control. Fungicide amended PDA medium was then poured aseptically in Petri plates $(7 \mathrm{~cm})$ and allowed to solidify. After solidification of medium, all the plates were inculcated aseptically with $5 \mathrm{~mm}$ culture disc of 7-day old culture of $S$. cepivorum and incubated at $18-20^{\circ} \mathrm{C}$ until mycelial growth of pathogenic fungi covered the surface of medium in control treatment (after 7 days). The percent of growth inhibition of the test pathogen was calculated using the formula according to Otadoh et al., 2011.

\section{Greenhouse experiment}

Greenhouse experiment was conducted to evaluate the effect of bioagents and folicur, alone or in combinations, on the incidence of onion white rot disease in the greenhouse. The experiment was carried out in pots against onion plants (Giza- 20) under outdoor conditions during 2016-2017 season. Pots (30 cm in diameter) were filed with sterilized soil. The experiment was carried out in a randomized complete block design with three replicates for each particular treatment. Pots infested with the most aggressive isolates $\left(\mathrm{I}_{5}\right)$. Glass bottles of $500 \mathrm{ml}$ capacity, containing $100 \mathrm{~g}$ barley grains and $50 \mathrm{ml}$ water, were autoclaved and then, they were inculcated with $5 \mathrm{~mm}$ diameter discs of pathogenic isolate using 10 days-old cultures and incubated at 18$20^{\circ} \mathrm{C}$ for 25 days. Fungal inoculum was mixed with the soil surface of each pot at rate of $20 \mathrm{~g} / \mathrm{kg}$ soil. The soil was then moistened with water for two weeks before transplanting.

\section{Preparation of the treatments}

Three fungal antagonists'viz., T. viride, T. harzianum and T. hamatum were grown on PDA plates for 10 days at $27 \pm 1^{\circ} \mathrm{C}$ then its growth was flooded with sterile-distilled water and scraped with a brush. A spore suspension of each fungal isolate was prepared approx. $1 \times 10^{7}$ spore $/ \mathrm{ml}$.

Folicur(Tebuconazole, alpha-[2-(4chlorophenyl) ethyl]-alpha-(1,1-dimethylethyl)-1H-1,2,4triazole-1- ethanol) was used at the recommended dose $(25 \mathrm{ml} / 1)$.

\section{Disease assessment}

After three months from sowing, the disease assessment was made based on the percentages of disease incidence (DI) and it was calculated using the following formula:

Disease incidence $=($ No. of dead plants $/$ Total sowing seedlings) $\times 100$

The percentage of efficiency was calculated as follows:

$\%$ Efficiency $=\mathrm{C}-\mathrm{T} / \mathrm{C} \times 100$, where: $\mathrm{C}=\%$ disease incidence in control treatment, $\mathrm{T}=\%$ disease incidence in different treatments.

\section{Effect of treatments on growth traits and yield of onion plants}

Growth characters of onion plants including plant height $(\mathrm{cm})$, fresh and dry weight $(\mathrm{g})$ were recorded in different treatments and control after 60 days of transplanting. At harvesting time, total onion yield per pots $(\mathrm{g})$ and total soluble solids (TSS) were calculated in each treatment.

\section{Statistical analysis}

Data were analyzed through one way analysis of variance (ANOVA) with the least significant difference (LSD) at the 0.05 probability level and Duncan's Multiple range test using CoStat Version 6.4 (CoHort Software, Monterey, CA).

\section{$\underline{\text { Results and Discussion }}$}

\section{Pathogenicity test of S. cepivorum}

Five isolates of $S$. cepivorum were collected and isolated from different localities of ELGharbia, El-Dakahlia and Giza Governorates. All obtained fungal isolates proved to be able to infect onion plants causing white rot symptoms. According to the results presented in Fig. 1, isolate No. $5\left(\mathrm{I}_{5}\right)$ recorded the highest percentage of infection (97.9\%), while isolate $\mathrm{I}_{3}$ showed the lowest $(37.5 \%)$. Isolate $\mathrm{I}_{5}$ was selected for further experiments. Differences in the pathogenicity of isolates tested might be due to the presence of genetic differences among the fungal isolates (Nattrass, 1932; Stewart and McLean, 2007).

\section{In vitro efficacy of bioagents}

Three fungal bioagents (T. viride, T. harzianum and $T$. hamatum) were evaluated in vitro against $\left(\mathrm{I}_{5}\right)$ the aggressive isolate of $S$. cepivorum. The results presented in Table (2) indicated that all the bioagents assessed showed fungistatic action and significantly inhibited mycelial growth of $S$. cepivorum. $T$. hamatum was the most effective that recorded the highest inhibition of mycelia growth by $100 \%$ (over growth) followed by T. viride (64.58\%) and T. harzianum (63.54\%). Trichoderma species were efficient in inhibiting the development of mycelial growth of $S$. cepivorum by direct competition, stimulation, and antibiosis by Trichoderma isolates (Benítez et al., 2004).

Environment, Biodiversity \& Soil Security Vol.1 (2017) 


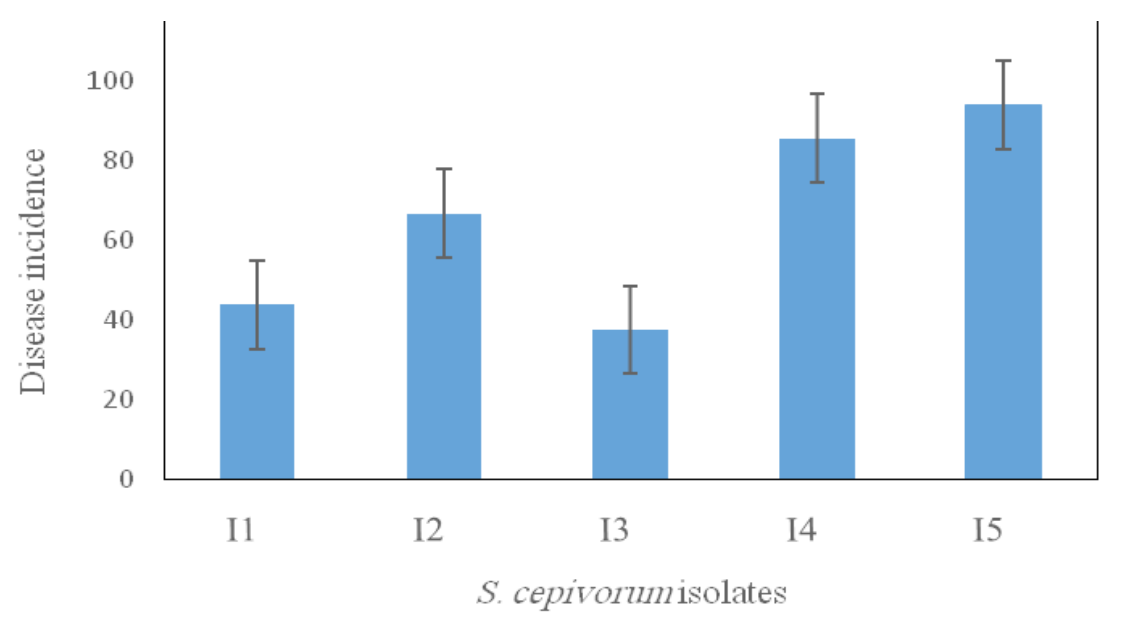

Fig. 1. Pathogenicity test of S. cepivorum isolates on onion cv. Giza 20 under greenhouse conditions.

TABLE 2. Effect of three bioagents against $S$. cepivorum.

\begin{tabular}{l} 
Bioagents Growth inhibition (\%) Bell scale \\
\hline TV \\
TH \\
THM \\
-Values are means of three replicates \pm SE in each treatment. \\
- TV: Trichoderma vride, TH: T. harzianum, THM: T. hamatu \\
In vitro efficacy of compost tea \\
Results in Table 3 revealed that compost tea \\
showed low inhibitory effect against radial growth \\
of the fungus and gave the maximum inhibition \\
(57.1\%) when applied at high concentration (100 mg/ \\
ml). Mechanisms of action underlying the efficacy of \\
compost tea in controlling plant pathogens have been \\
reported as single or multiple mechanisms involving \\
microbial antagonism (through antibiosis, parasitism, \\
competition for nutrients /space or induced plant \\
resistance) (Al-Mughrabi et al., 2008)or suppressive \\
physicochemical properties (improved nutrient status \\
of the plant, toxic compounds or induced resistance) \\
(Siddiqui et al., 2008). This was supported by Noble \\
and Coventry (2005) who demonstrated that disease \\
suppressive effect of compost tea against Pythium \\
ultimum, Rhizoctonia Solani, Phytophthora Spp, \\
Fusarium Oxysporium and Verticillium dahliae \\
was increased due to increase rate of application \\
to at least 20\%.
\end{tabular}

In vitro efficacy of fungicide folicur

Results in Table 4 indicated that fungicide (folicur) has significant inhibited mycelial growth of $S$. cepivorum. In addition it was found that percent inhibition was increased with the increase in concentration of the fungicides. Foilcur was

Environment, Biodiversity \& Soil Security Vol.1 (2017) found complete inhibition $(100 \%)$ at $0.2 \mathrm{ppm}$ concentration and with $\mathrm{IC}_{50}$ values ppm 0.036 . Pung, (2008) assessed in vitro the efficacy of Folicur to reduce the mycelial growth of the onion white rot disease. Complete fungal inhibition was recorded at $1 \mathrm{ppm}$. At lower fungicide levels, it only causes partial inhibition of the pathogen.

Efficacy of bioagents, folicur and their combinations in greenhouse

The ability of three bioagents and fungicide Folicur, alone or in combinations, to control $S$. cepivorum were evaluated under greenhouse conditions. The results in Table 5 indicated that disease incidence was significantly reduced in all treatments in comparison with the control. No significant differences were found between the efficiency values exhibited by folicur alone (75.0\%), T. harzianum combined with T. hamatum (70.8\%), folicur combined with $T$. viride and T. harzianum $(70.8 \%)$, folicur combined with T. viride $(62.5 \%)$, folicur combined with $T$. harzianum $(62.5 \%)$, Folicur combined with $T$. hamatum $(62.5 \%)$ and folicur combined with $T$. viride and T. hamatum(62.5\%).

Furthermore, results in Table 6 revealed that vegetative growth parameters of onion plants were significantly increased as a response to treatment with bioagents individually or in combination with fungicide folicur. Meanwhile, a significant increase in onion bulb yield was recorded in the bioagents treatments alone or in combination with folicur and the highest increase was found in the folicur alone $(216.4 \mathrm{~g} / \mathrm{pot})$ followed by $T$. harzianum combined with T. hamatum (192.6g/ pot). Additionally, some treatments significantly increased TSS in onion bulbs and the highest increase was recorded in folicur (16.0\%). 
TABLE 3. Effect of compost against the aggressive isolate of S. cepivorum.

\begin{tabular}{cc}
\hline Concentration (mg/ml) & Growth inhibition (\%) \\
\hline 25 & $42.85 \pm 0.001$ \\
50 & $50.0 \pm 0.001$ \\
75 & $54.28 \pm 0.001$ \\
100 & $57.14 \pm 0.001$ \\
$\mathrm{IC}_{50}$ & 61.96 \\
\hline - Values are means of three replicates $\pm \mathrm{SE}$. \\
$-\mathrm{IC}_{50}:$ Inhibitory concentration (the concentration in $\mathrm{mg} / \mathrm{ml}$ \\
that inhibits $50 \%$ of the fungus).
\end{tabular}

TABLE 4. Effect of fungicide (Folicur) against the aggressive isolate of $S$. cepivorum .

\begin{tabular}{ll}
\hline Concentrations (ppm) & Growth inhibition (\%) \\
\hline 0.02 & $30.00 \pm 0.00$ \\
0.05 & $59.04 \pm 0.47$ \\
0.2 & $100.0 \pm 0.00$ \\
0.4 & $100.0 \pm 0.00$ \\
0.8 & $100.0 \pm 0.00$ \\
1 & $100.0 \pm 0.00$ \\
$\mathrm{IC}_{50}$ & 0.036 \\
\hline
\end{tabular}

TABLE 5. Effect of the bioagents and folicur alone or in combinations on disease incidence of white rot disease.

\begin{tabular}{lcc}
\hline Treatments & Disease incidence (\%) & Efficiency \\
\hline Control & $87.5 \pm 0.0 \mathrm{a}$ & - \\
TV & $50.0 \pm 0.0 \mathrm{~b}$ & 37.5 \\
THM & $54.2 \pm 4.2 \mathrm{~b}$ & 33.3 \\
TH & $54.2 \pm 4.2 \mathrm{~b}$ & 33.3 \\
F & $12.5 \pm 0.0 \mathrm{e}$ & 75.0 \\
TV + THM & $29.2 \pm 4.2 \mathrm{~cd}$ & 58.3 \\
TV + TH & $33.3 \pm 4.2 \mathrm{c}$ & 54.2 \\
TH + THM & $16.7 \pm 4.2 \mathrm{de}$ & 70.8 \\
TV + THM + TH & $37.5 \pm 0.0 \mathrm{c}$ & 50.0 \\
F + TV & $25.0 \pm 0.0 \mathrm{cde}$ & 62.5 \\
F + TH & $25.0 \pm 0.0 \mathrm{cde}$ & 62.5 \\
F + THM & $25.0 \pm 0.0 \mathrm{cde}$ & 62.5 \\
F + TV + THM & $25.0 \pm 0.0 \mathrm{cde}$ & 62.5 \\
F + TV + TH & $16.6 \pm 4.2 \mathrm{de}$ & 70.8 \\
F + THA + THM & $33.3 \pm 4.2 \mathrm{c}$ & 54.2 \\
F + TV + THM + TH & $33.3 \pm 4.2 \mathrm{c}$ & 54.2 \\
LSD 0.05 & 8.48 & - \\
\hline Values are means of three replicates in each treatment \pm SE & & \\
- TH & & \\
& &
\end{tabular}

- Values are means of three replicates in each treatment \pm SE.

- Means values in each column followed by the same letter are not significantly different $(\mathrm{P} \leq 0.05)$.

- TV: Trichoderma vride, TH: T. harzianum, THM: T. hamatum, F: Folicur.

Trichoderma spp. have a lot of mechanisms to reduce disease severity and increase vegetative growth for plant such as, as production of growth hormones, solubilization of insoluble minor nutrients in soil and increased uptake and translocation of less-available minerals (Kleifeld and Chet, 1992; Near et al., 1994). Trichoderma strains grow rapidly when inoculated in the soil, because they are naturally resistant to many toxic compounds, including herbicides, fungicides and pesticides such as DDT and phenolic compounds (Chet et al., 1997). Trichoderma strains are very effective in controlling many phytopathogens such as $R$. solani, $P$. ultimum and Sclerotium rolfsii, when alternated with methyl 
TABLE 6. Effect of the bioagents alone or in combinations with folicur against onion growth and yield.

\begin{tabular}{|c|c|c|c|c|c|}
\hline \multirow[b]{2}{*}{ Treatments } & \multicolumn{3}{|c|}{ Vegetative growth } & \multicolumn{2}{|c|}{ Yield and quality } \\
\hline & $\begin{array}{c}\text { Plant height } \\
(\mathrm{cm})\end{array}$ & $\begin{array}{l}\text { Plant fresh } \\
\text { weight (g) }\end{array}$ & $\begin{array}{l}\text { Plant dry } \\
\text { weight (g) }\end{array}$ & $\begin{array}{c}\text { Bulb weight/ } \\
\text { pot (g) }\end{array}$ & TSS (\%) \\
\hline Control (infected) & $38.0 \pm 1.2 \mathrm{~g}$ & $13.6 \pm 0.3 \mathrm{~g}$ & $1.9 \pm 0.04 \mathrm{e}$ & $33.4 \pm 1.2 \mathrm{~h}$ & $11.7 \pm 0.3 \mathrm{~d}$ \\
\hline Control (healthy) & $56.0 \pm 1.6 \mathrm{a}$ & $32.6 \pm 0.2 \mathrm{a}$ & $6.9 \pm 0.1 \mathrm{a}$ & $248.1 \pm 1.5 \mathrm{a}$ & $16.0 \pm 0.33 \mathrm{a}$ \\
\hline TV & $50.3 \pm 0.3 \mathrm{bc}$ & $19.2 \pm 0.6 \mathrm{de}$ & $4.9 \pm 0.6 \mathrm{bc}$ & $66.6 \pm 3.6 \mathrm{~g}$ & $12.2 \pm 0.2 \mathrm{~d}$ \\
\hline THM & $50.0 \pm 0.6 \mathrm{bc}$ & $21.4 \pm 1.7 \mathrm{~d}$ & $5.9 \pm 0.2 \mathrm{ab}$ & $66.59 \pm 4.6 \mathrm{~g}$ & $12.0 \pm 0.5 \mathrm{~d}$ \\
\hline $\mathrm{TH}$ & $52.0 \pm 1.1 \mathrm{abc}$ & $19.4 \pm 0.4 \mathrm{de}$ & $4.6 \pm 0.4 \mathrm{bc}$ & $71.98 \pm 1.0 \mathrm{~g}$ & $14.2 \pm 0.1 \mathrm{bc}$ \\
\hline $\mathrm{F}$ & $52.3 \pm 1.2 \mathrm{abc}$ & $29.5 \pm 0.3 \mathrm{~b}$ & $4.8 \pm 0.3 \mathrm{bc}$ & $216.4 \pm 1.7 \mathrm{~b}$ & $16.0 \pm 0.3 \mathrm{a}$ \\
\hline $\mathrm{TV}+\mathrm{THM}$ & $53.0 \pm 0.6 \mathrm{abc}$ & $16.9 \pm 0.4 \mathrm{ef}$ & $3.4 \pm 0.4 \mathrm{~d}$ & $103.4 \pm 5.8 \mathrm{f}$ & $14.8 \pm 0.4 \mathrm{~b}$ \\
\hline $\mathrm{TV}+\mathrm{TH}$ & $52.3 \pm 1.2 \mathrm{abc}$ & $16.7 \pm 0.8 \mathrm{f}$ & $3.6 \pm 0.2 \mathrm{~cd}$ & $105.9 \pm 5.2 \mathrm{f}$ & $14.0 \pm 0.0 \mathrm{bc}$ \\
\hline $\mathrm{TH}+\mathrm{THM}$ & $51.3 \pm 0.7 \mathrm{abc}$ & $19.3 \pm 0.2 \mathrm{de}$ & $5.0 \pm 0.4 \mathrm{bc}$ & $192.6 \pm 2.1 \mathrm{c}$ & $14.0 \pm 0.0 \mathrm{bc}$ \\
\hline $\mathrm{TV}+\mathrm{THM}+\mathrm{TH}$ & $48.7 \pm 0.7 \mathrm{~cd}$ & $14.9 \pm 0.2 \mathrm{fg}$ & $2.7 \pm 0.5 \mathrm{de}$ & $155.1 \pm 2.6 \mathrm{e}$ & $14.3 \pm 0.4 \mathrm{bc}$ \\
\hline $\mathrm{F}+\mathrm{TV}$ & $52.3 \pm 1.2 \mathrm{abc}$ & $24.0 \pm 0.5 \mathrm{c}$ & $5.8 \pm 0.3 \mathrm{ab}$ & $108.2 \pm 4.9 \mathrm{f}$ & $14.0 \pm 0.3 \mathrm{bc}$ \\
\hline $\mathrm{F}+\mathrm{TH}$ & $51.3 \pm 0.7 \mathrm{abc}$ & $15.2 \pm 0.3 \mathrm{fg}$ & $2.7 \pm 0.28 \mathrm{de}$ & $174.0 \pm 2.2 \mathrm{~d}$ & $13.7 \pm 0.4 \mathrm{bc}$ \\
\hline $\mathrm{F}+\mathrm{THM}$ & $53.7 \pm 0.9 \mathrm{ab}$ & $17.1 \pm 0.2 \mathrm{ef}$ & $5.1 \pm 0.19 b$ & $169.1 \pm 5.0 \mathrm{~d}$ & $13.5 \pm 0.2 \mathrm{c}$ \\
\hline $\mathrm{F}+\mathrm{TV}+\mathrm{THM}$ & $51.7 \pm 0.9 \mathrm{abc}$ & $20.8 \pm 0.9 \mathrm{~d}$ & $5.7 \pm 0.4 \mathrm{ab}$ & $175.1 \pm 1.0 \mathrm{~d}$ & $12.7 \pm 0.5 \mathrm{~d}$ \\
\hline $\mathrm{F}+\mathrm{TV}+\mathrm{TH}$ & $46.3 \pm 0.9 \mathrm{de}$ & $13.9 \pm 0.4 \mathrm{~g}$ & $4.8 \pm 0.4 \mathrm{bc}$ & $174.2 \pm 2.7 \mathrm{~d}$ & $12.5 \pm 0.0 \mathrm{~d}$ \\
\hline $\mathrm{F}+\mathrm{THA}+\mathrm{THM}$ & $44.0 \pm 1.0$ ef & $16.4 \pm 0.3 \mathrm{f}$ & $5.2 \pm 0.1 \mathrm{bc}$ & $170.3 \pm 2.4 \mathrm{~d}$ & $12.7 \pm 0.3 \mathrm{~d}$ \\
\hline $\mathrm{F}+\mathrm{TV}+\mathrm{THM}+\mathrm{TH}$ & $41.3 \pm 1.3 \mathrm{f}$ & $13.8 \pm 0.2 \mathrm{~g}$ & $2.7 \pm 0.23 \mathrm{de}$ & $174.2 \pm 5.5 \mathrm{~d}$ & $14.5 \pm 0.0 \mathrm{bc}$ \\
\hline LSD 0.05 & 2.85 & 1.72 & 0.95 & 10.13 & 0.79 \\
\hline
\end{tabular}

- Values are means of three replicates in each treatment \pm SE

- Means values in each column followed by the same letter are not significantly different $(\mathrm{P} \leq 0.05)$.

- TV: Trichoderma vride, TH: T. harzianum, THM: T. hamatum, F: Folicur, TSS: Total soluble solids.

bromide, benomyl, captan or other chemicals (Vyas and Vyas, 1995).Some researchers also reported that combinations of tebuconazole and a biocontrol agent enhanced the control of onion white rot (Clarkson et al., 2006).

\section{Conclusions}

Mixing the soil surface with Trichoderma vride, T. harzianum or T. hamatum alone or in a combination with the fungicide folicur could be recommended for controlling the white-rot disease in onion plants caused by $S$. cepivorum and enhancing the vegetative growth and bulb yield of onion plants.

\section{References}

Abd El-Moity, T. H. (1976) Studies on the biological control of white rot disease of onion. M. Sc. Thesis Fac. of Agric. Monoufia Univ.

Ahmed, H.A.M., and Ahmed, N. G. (2015) Management of white rot of onion using composts and Trichoderma harzianum. Current Life Sciences, 1(2), 63-69.

AL-Mughrabi, K. I., Berthélémé, C., Livingston, T., Burgoyne, A., Poirier, R. and Vikram, A. (2008) Aerobic compost tea, compost and a combination of both reduce the severity of common scab (Streptomyces scabiei) on potato tubers. J. Plant

\section{Sci., 3, 168-175.}

Bell, D.K., Well, H. D. and Markham, C. R. (1982) In vitro antagonism of Trichoderma species againstsix fungal plant pathogens. Phytopathology, 72:379382. DOI: 10.1094/Phyto-72-379.

Benítez, T., Rincón, A. M., Limón, M. C., and Codón, A. C. (2004) Biocontrol mechanisms of Trichoderma strains. International Microbiology, 7(4), 249-260.

Brown, W., 1924. A Method of isolating single strains of fungi by cutting out a hyphal tip. Annals of Botany, 38(150), 402-404.

Castillo, F.D., Padilla, A.M., Morales, G.G., Siller, M.C., Herrera, R.R., Gonzales, C.N., and Reyes, F.C. (2011) In vitro antagonist action of Trichoderma strains against Sclerotinia sclerotiorum and Sclerotium cepivorum. American Journal of Agricultural and Biological Science. 6,410-417.

Cherif, S.S. and Benhamou, C. S. (1990) Cytochemical aspects of chitin breakdown during the parasitic ction of a Trichoderma spp. on Fusarium oxysporum f. sp. radicans-lycopersici. Phytopathology. 80:1406-1414. doi: 10.1094/Phyto-80-1406.

Chet, I., Inbar, J., and Hadar, I. (1997) Fungal antagonists and mycoparasites. The Mycota Iv: Environmental And Microbial Relationships. Springer-Verlag, Berlin, 165-184. 
Ciements F.E., Shear C.L. (1957) The Genera Of Fungi Hafner Publishing Co. New York.

Clarkson, J. P., Scruby, A., Mead, A., Wright, C., Smith, B., and Whipps, J. M. (2006) Integrated control of Allium white rot with Trichoderma viride, tebuconazole and composted onion waste. Plant Pathology, 55(3), 375-386.

Davis, R.M., Hao, J. J., Romberg, M. K., Nunez, J. J. and Smith, R. F. (2007). Efficacy of germination stimulants of sclerotia of Sclerotium cepivorum for management of white rot of garlic. Plant Disease, 91(2), 204-208.

FAO. (2014) Food and Agriculture Organization of the United Nations, FAOSTAT Agriculture Data. http://www.fao.org/faostat/en/\#data/QC http:// faostat3.fao.org/browse/Q/QC/E(accessed August 21, 2017).

Otadoh, J.A., Okoth, S.A., Ochanda, J. and Kahindi, J.P., (2011) Assessment of Trichoderma isolates for virulence efficacy on Fusarium oxysporum F. sp. Phaseoli. Tropical and Subtropical Agroecosystems, 13, 99-107.

Kleifeld, O., and Chet, I. (1992) Trichoderma-plant interaction and its effect on increased growth response. Plant Soil, 144(2), 267-272.?

Maude R.B. (2006) Onion Diseases. In: The Epidemiology of Plant Diseases Cooke BM, Jones DG, Kaye B, (Eds.), Vol 19, Springer, USA.

Nattrass R.M. (1932) The occurrence of the white rot of onion, Sclerotium cepivorum Berk. Egypt. Min. Agric., Egypt. Tech. Sci. Service (Plant Protect. Sect.) Bull. 1931; 107: 9. (R.A.M. 11, 219-220).

Near, J., Abramsky, M., Cohen, D., and Chet, I. (1994) Plant growth enchancement and disease control by Trichoderma harzianum in vegetable seedlings grown under commercial conditions. European journal of plant pathology.

Noble, R., and Coventry, E. (2005) Suppression of soil-borne plant diseases with composts: a review. Biocontrol Science and Technology, 15(1), $3-20$.

Pung, H. (2008). Investigations into early and late fungicide applications for onion white rot control in Australia. Onions Australia, 25, 10-13.

Siddiqui, Y., Meon, S., Ismail, M. R. and Ali, A. (2008) Trichoderma fortified compost extracts for the control of choanephora wet rot in okra production. Crop Prot., 27, 385-390.

Stewart A., and McLean, K. L. (2007) Biological control of onion white rot. Chapter 6. In: Biological Control Of Plant Diseases. The Haworth Press, Inc. 123-148.
Vyas, S. C., and Vyas, S. (1995) Integrated control of dry root of soybean. Modern fungicides and antifungal compounds. Intercept, Andover, 565572.

Yesuf, M., (2013). Searching and evaluating of cost effective management options of garlic white rot (Sclerotium cepivorum Berk) in Tigray, Northern Ethiopia. Journal of Plant Pathology \& Microbiology, 2013.

(Received 22 /8/ 2017; acecpted $10 / 9 / 2017$ ) 